\title{
Chitosan Nanogel Design on Gymnema sylvestre Essential Oils to Inhibit Growth of Candida albicans Biofilm and Investigation of Gene Expression ALS1, ALS3
}

\author{
Sepideh Akbari1, Mansour Bayat ${ }^{1 *}$, Shahla Roudbarmohammadi², Jamal Hashemi \\ 1 Department of Microbiology, Faculty of Veterinary Specialized Sciences, Science and Research Branch, Islamic Azad University, \\ P.O. Box 755-14515, Tehran, Iran \\ 2 Department of Medical Mycology, Faculty of Medical Science, Tarbiat Modares University, P.O. Box 14115-111, Tehran, Iran \\ ${ }^{3}$ Department of Medical Parasitology and Mycology, School of Public Health Tehran University of Medical Science, \\ P.O. Box 1417653761, Tehran, Iran \\ *Corresponding author, e-mail: m.bayat@srbiau.ac.ir
}

Received: 12 May 2018, Accepted: 28 August 2018, Published online: 16 April 2019

\begin{abstract}
Chitosan (CS) is a polycation with a pka of about 6.3 with a charge density dependent on $\mathrm{pH}$ and the \%DA-value which can interact with polyanions to form complex and gels. Nanoparticles (CNPs) in addition can increase the antifungal potential of bioactive compounds like essential oils by increasing cellular interactions between them and the fungal as a result of the very small size that enhances cellular uptake. In this study, was set to investigate the encapsulation of the Gymnema sylvestre essential oils (G.EOs) using Chitosan and Myrestic acid made Nanogel in order to enhance its antifungal activity and stability to the oil against C. albicans strain (ATCC 10231). To procedure this, the self-assembled process of Chitosan and Myrestic acid Nanogel (CS-MA) through the 1- ethyl - 3- (3 dimethyl aminoprophyl) carbodiimide (EDC) was designed. Its physicochemical properties were determined by Fourier Transforms Infrared spectroscopy (FTIR), X-ray diffraction (XRD), and microscopic methods by Atomic force microscopy (AFM), Transmission Electron Microscopy (TEM), and Scanning Electron Microscopy (SEM). Minimum inhibitory concentration (MIC) at 18.7 to $37.5 \mu \mathrm{g} / \mathrm{ml}$ and 2.3 to $4.6 \mu \mathrm{g} / \mathrm{ml}$ and minimal fungicidal concentration (MFC) at $75 \mu \mathrm{g} / \mathrm{ml}$ and $5.38 \mu \mathrm{g} / \mathrm{ml}$ using by broth micro dilution (BMD) method for G. sylvestre oils (G.EOs) and oil-loaded Nanogels (G.OLNPs) were measurement. The susceptibility of C. albicans biofilm to fractions was examined by 2,3-bis (2-methoxy-4-nitro-5-sulfophenyl)-5-[8phenylamino)carbonyl]-2H-tetrazolium hydroxide (XTT) quantitatively.

The concentration of G.OLNPs required to inhibit $50 \%$ biofilm formation was $4.68 \mu \mathrm{g} / \mathrm{ml}$, while that to remove $90 \%$ biofilm growth was $18.07 \mu \mathrm{g} / \mathrm{ml}$. In addition, it was observed that cell uptake of G.OLNPs was much higher compared with free G.EOs. Reverse transcription polymerase chain reaction (RT-PCR) analysis was performed to determine the effect of sub-MIC concentrations of G.EOs and G.OLNPS on expression of the biofilm-related gene ALS1/ALS3, and indicated the G.OLNPs down-regulated the expression of hypha-specific gene ALS3. Furthermore, the data strongly suggested that G.OLNPs more effective suppressed C. albicans planktonic cells and reduction biofilm biomass.
\end{abstract}

Keywords

Candida albicans, Gymnema sylvestre, Chitosan Nanogel, XTT assay, ALS1 and ALS3

\section{Introduction}

Candida species are the prevalent human fungal pathogen that poses the significant medical challenge [1]. In recent decades systemic infection caused by the $C$. albicans in immunosuppressed patients such as transplant recipients and cancer patients undergoing cytotoxic chemotherapy, Diabetes, a variety of hematologic malignancy and HIV, have been increased [2]. Most manifestations of candidiasis are associated with biofilm formation (BF) occurring on the surface of host tissue and medical devices, which plays an essential role in the pathogenicity of $C$. albicans $[3,4]$. Biofilm is a complex network of microorganism's accumulation in a matrix Exo-polymer hydrophobic which can be attached to various biotic and abiotic surfaces [5, 6].

The transition from the yeast to the hyphal form allows the pathogen not only to invade tissue and causes oxidative stress resistance but also to escape from immune surveillance, it 
can facilitate the adhesion of other microorganisms is conducive to fungal diseases [7, 8]. Lastly, degrading hydrolases, phenotypic switching, and adherence to host surfaces and the secreted aspartyl proteinase and lipase families are associated by a large gene family, particularly the agglutinin-like sequence (ALS) $[9,10]$. The ALS gene family is the largest family among known adhesions in C. albicans [10]. Each ALS gene has a similar three-domain structure, including a $5^{\prime}$ domain of $1299-1308$ bp that is $55 \%-90 \%$ identical across family; a central domain is composed of a $108 \mathrm{bp}$ motif repeating. This domain is responsible for encryption protected of 36 amino acids and a 3' domain has a variable length but the sequence alkaline with other members of the gene has a similar structure [11]. The finding that expression of ALS1 and ALS3 increases during biofilm development in vitro suggested that the ALS family played a role in biofilm formation [12]. Recently, Bastidas et al. [13] found that expression of ALS3 inhibited under conditions of high nutrient availability.

A common issue associated with $C$. albicans biofilms is the increased resistance of these biofilms to antifungal agents such as azole drugs and their derivatives and to host immune defences [14, 15]. Resistance mechanisms such as limited influence of drugs due to fungus-resistant matrix, switch phenotype leading to slower growth or food restrictions with gene expression ALS1/ALS3 is increased and to lead resistance to antibiotic treatment [16, 17]. Therefore, it has become an urgent medical that needs to develop a safer and better drug delivery system increasingly. Pharmaceutical sciences to reduce toxicity or side effects of drugs used nanoparticles (NPs).Among these polymeric NPs, chitosan (CS)-based nanocarriers (CSNPs) have received much attention as a drug-delivery system.

Chitosan is a liner polysaccharide composed of randomly distributed $\beta$-(1 $\rightarrow 4)$-link D-glucosamine (deacetylated unit) and N-acetyl-D-glucosamine (acetylated unit) [18]. The $\mathrm{NH}_{2}$ - and $\mathrm{OH}$ - groups endow chitosan with many special properties, making it applicable to many areas and easily available for chemical reactions [19]. After structural manipulation and functionalization of CS, drug molecules can be encapsulated and the advantages of it allow for a greater control of the active drug pharmacokinetic behaviour [20].

These methods, in principle, can be divided into, crosslinked networks of the polymer chain formed via covalent linkage or self-assembly process. The present study was set to produce Nanogel through the formation amid linkages between amino group of chitosan, to the carboxyl group in myristic acid $\left(\mathrm{MA} ; \mathrm{C}_{14} \mathrm{H}_{28} \mathrm{O}_{2}\right.$ ) by self-assembly technique [21]. The reaction to the formation of hydrogen nanoparticles that can be encapsulated or controlled release of the drug used [3].

In their investigation, Rabea et al. [22] and Sudarshan et al. [23] reported that nano chitosan cuts down the metabolic activity and durability of Candida species biofilms. This phenomenon may be caused by a tension in the biofilm structure that increases the permeability of cell membranes, penetration of nano chitosan, and fungus removal. Shrestha et al. [24] showed that fungal biofilm was significantly reduced after exposure to nano chitosan particles.

In addition, due to their nano scaled dimension Nanogels are responsive to the effects of environmental factors such as light, ionic strength, $\mathrm{pH}$, and temperature on bioactive compounds such as essential oils (EOs). The plant mediated synthesis is a rapid, flexible and suitable process for large scale production of nanoparticle.

Gymnema sylvestre is one of the most important medical plants in India and belongs to the family of Asclepiadaceae [25]. G. sylvestre is otherwise popularly known as gurmar and Madhunashini. Essential oils this plant consisted of flavonoids, and alkaloids are major groups of phenolic compounds [26]. Gymnemic acids (GAs) are reported to be the main class of chemical constituents of G. sylvestre is known for its significant antidiabetic, antifungal and antibacterial properties against various pathogenic population activities (Scheme 1).

The objective of this research was to evaluate the effect of the fabrication of CSNPs based on, antifungal activity. G. sylvestre essential oils (G.EOs) and essential oils loading in Nanogels (G.OLNPs) have on efficient impacted on growth of the planktonic cells and biofilm formation (BF) C. albicans strain ATCC 10231. In addition, RT - PCR was discussed on treated and untreated ALS1/ALS3 gene expression in sessile cells of $C$. albicans.

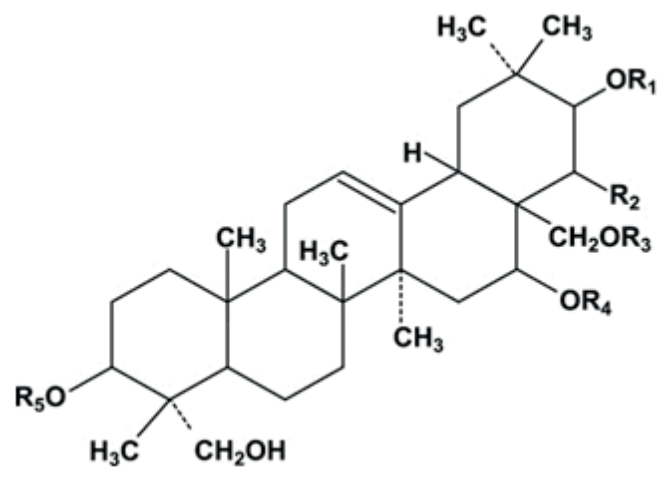

Scheme 1 Basic structure of Gymnemic acids (GAs) 


\section{Materials and Methods}

\subsection{Formation and characterization of the G.OLNPs}

\subsubsection{Preparation of CS-MA (Chitosan- Myristic acid)} Nanogel

The water-soluble $\mathrm{EDC}^{1}$ is called "Zero-length" Crosslinker because the amide linkage is formed without leaving a spacer molecule [27]. CS-MA Nanogel was designed for preservation and controlled release of G.EOs by the technique of self-assembly according to a modification of the method of Chen et al [28].

Myristic acid solution was prepared by dissolving $0.1 \mathrm{gr}$ MA (Sigma Aldrich $\geq 99 \%, \mathrm{Mw}=228.37 \mathrm{~g} / \mathrm{mol}$ ) in $10 \mathrm{~mL}$ ethanol. Chitosan $(1 \mathrm{~g})$ (Sigma Aldrich, degree of deacetylation (DD): 75-85\%, medium molecular weight of: $250 \mathrm{kDa}, 200-800 \mathrm{cP}$ viscosity of $\% 1 \mathrm{w} / \mathrm{v}$ ) was dissolved in $100 \mathrm{~mL}$ aqueous acetic acid $(1 \% \mathrm{v} / \mathrm{v} ; \mathrm{pH}=3.35)$ solution and sonicated using a probe type sonifire (ultrasonic homogenizer VH-600) at $60 \mathrm{w}$ for $20 \mathrm{~min}$ and then diluted with methanol. Polymer complex of myristic acid and chitosan covalently joined together by the formation of amide linkages through the EDC (Sigma-Aldrich, $\mathrm{Mw}=155.24 \mathrm{~g} / \mathrm{mol}, \mathrm{d}=0.814 \mathrm{~g} / \mathrm{mL}$ ) mediated reaction. EDC $(0.1 \mathrm{~g})$ and $\mathrm{NHS}^{2}(0.1 \mathrm{~g})$ was dissolved in methanol, then added into the MA solution. The 1:1 mol ratio of EDC to MA was utilized in this paper.

EDC reacts with the carboxyl group of MA to form an active ester intermediate, which can further react with a primary amine of CS to form an amide bond. Afterwards, MA solution was added to the chitosan solution followed by a drop wisely, while stirring under the hood at room temperature for $24 \mathrm{~h}$ [29]. The precipitated material was washed with distilled water and ethanol by ultracentrifuge and dried under vacuum for $24 \mathrm{~h}$ at room temperature. Dried Nanogels were kept in a refrigerator at $4{ }^{\circ} \mathrm{C}$ until required in the analysis (Scheme 2).

\subsection{Physicochemical characterization of G.OLNPs}

\subsubsection{Scanning Electron Microscopy (SEM) analysis}

SEM is a method for high resolution imaging of surface. Sample was prepared on a glass slide $(1 \times 1 \mathrm{~cm})$ after washing it with ethanol. A tiny drop of nano dispersion was spread evenly over glass slide and allowed to air dry. Morphology and size G.OLNPs consist of the surface and shape nano capsule walls were observed by using Philips: XL30 analytical SEM.

1 1-ethyl-3-(3-dimethylaminopropyl ) carbodiimide hydrochloride. 2 N-hydroxysuccinimide

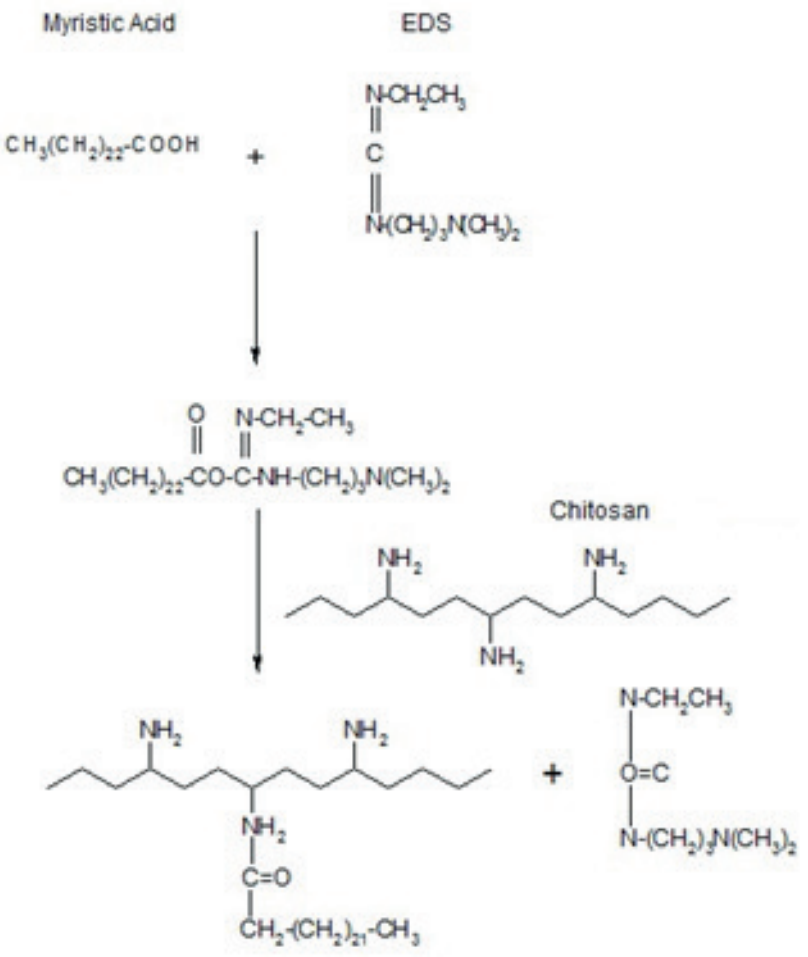

Scheme 2 Myristic acid modified chitosan

\subsubsection{D Structure Evaluation: Atomic force} microscopy (AFM)

While SEM provides 2 dimensional (2D) images of sample, AFM studies were performed to get the 3 dimensional (3D) images. AFM imaging was carried out by using scanning probe microscope (Entegra Afmnt-mdt; Company: NT-MDT) in tap model. Samples were prepared in a fashion as for SEM analysis without any further sample treatment.

\subsubsection{Transmission Electron Microscopy (TEM)}

Morphological characteristics, bio reductive formation and existence of CS-MA Nanogel was analysed by high-resolution TEM. One drop of the sample suspensions was placed on carbon-coated TEM grids. After one minute, the grids were dried using filter paper and the nanostructure was conducted with a Philips EM208S Transmission electron microscope (Germany) at acceleration voltage of $100 \mathrm{kV}$ [30].

\subsubsection{Release kinetics of G.OLNPs analysis}

To determine release pattern G.OLNPs was assessed by spectrophotometer. The amount of $1 \mathrm{mg}$ of the formulation was transferred into dialysis bags (molecular weight cut-off, 6-8 kDa) in $25 \mathrm{ml}$ of buffer PBS ( $\mathrm{pH}=7.4)$ and sonicated (Sonic Purger CQ250) in water bath at room temperature for $5 \mathrm{~min}$ and afterwards shaken horizontally (Incubator Shaker HZ-88125) during a one-week period. 
After that, the drug released in the buffer solution was measured at a wavelength $195 \mathrm{~nm}$ by spectrophotometry. Finally, the percentage of drug release was prepared using the standard curve and monitoring afterwards.

The Nanogel release profile was determined using Eq. (1):

$M t / M \infty=K t^{n}$

where $M t / M \infty$. It denotes the fraction of oil released $(t)$ is the release time, and $(K)$ represents a constant characteristic of the system [31]. The diffusion exponent $(n)$ is an indication of the mechanism of oil release and takes values depending on the geometry of the release device. A linear form of Eq. (1) can be obtained by plotting $\ln M t / M \infty$ against $\ln t$, whose angular coefficient is $n$ and the linear coefficient is $k$.

\subsubsection{X-ray Diffraction (XRD)}

The pattern of transparency of CS-MA Nanogel with a WR of 0.2 were recorded in powdered thin film of Nanogel at 500 $\mathrm{nm}$ using X-ray diffractometer (Lamda 35, Perkin-Elmer) at 1 step / second. The method is non-destructive and does not require sample preparation. The diffraction patterns was set up to determine the crystalline phases of the sample and measuring the structural properties. Data was taken for the at $2 \Theta$ range of 4 to 88 degrees with a step size of $0.001^{\circ}$.

\subsubsection{Fourier Transformation Infrared Spectrometry (FTIR) analysis}

In order to, interaction and bonding analysis of EOs with CSNPs Nanogel FTIR studies were conducted to get information about an effective drug delivery system. It is necessary that the active agent must be released slowly from the carrier moiety. Spectrums of Infrared Radiation (IR) were recorded by the 460-type spectrometer (Shimudza Co. Japan) under dry air at room temperature, following the method described [32]. For the IR spectroscopic analysis, $2 \mathrm{mg}$ of MA, $2 \mathrm{mg}$ of CS and $100 \mu \mathrm{l}$ of CS-MA Nanogel was separately mixed with $100 \mathrm{mg}$ of $\mathrm{KBr}$ and made into pellets at $20{ }^{\circ} \mathrm{C}$. The instrument was operated with frequency range of 500-4000 $\mathrm{cm}^{-1}$. The resulted peaks in the FTIR spectrum were used to derive a dose-response curve and provide pharmacological information [33].

\subsection{Antifungal Activity}

\subsubsection{Preparation of standard fungal cell suspension}

Candida albicans (strain 10231) was purchased from the American Type Culture Collection (ATCC). The fungal cells were grown on YPD agar $[1 \%(\mathrm{w} / \mathrm{v})$ yeast extract, $2 \%$ (w/v) mycological pepton, $2 \%$ dextrose, $2 \%$ agar], at $35^{\circ} \mathrm{C}$ for $24 \mathrm{~h}$ with agitation and passaged at least twice to ensure purity and viability. Inocula was prepared by picking five colonies of about $1 \mathrm{~mm}$ in diameter from 24-h-old cultures of Candida albicans [34]. The colonies were suspended in $5 \mathrm{ml}$ of phosphate-buffered saline (PBS; $\mathrm{pH}=7.2$ ). The resulting suspension was vortexed for $15 \mathrm{~s}$, and the cell density was adjusted to an optical density at $520 \mathrm{~nm}$. This procedure yield a yeast stock suspend $\left(1 \times 10^{3}\right.$ cells $\left./ \mathrm{mL}\right)$.

\subsubsection{Antifungal effect of compounds against planktonic cells}

For individual susceptibility profile of planktonic cells, broth microdilution (BMD) assay was performed based on version of M27-A3 documents according to the guidelines of CLSI (Clinical and Laboratory Standards Institute) [35, 36]. Stock suspensions of the antifungal agents of G.EOs and Itraconazole (ITZ; Janssen Research Foundation, Beerse, Belgium) according to the manufacturer's instructions were added with sterile DMSO (dimethyl sulfoxide; Sigma Chemical Co., St. Louis, MO, USA) and was diluted in the standard RPMI 1640 medium (Sigma Chemical Co. Germany) buffered with morpholine propane sulfonic acid (MOPS pH $=7.0$; 0. 165 mol L; Sigma) with L-glutamine without biocarbonate to yield two times their concentrations [37]. Briefly, two-fold of serial doubling dilutions of G.EOs $(2.3 \mu \mathrm{g} / \mathrm{mL}$ to $300 \mu \mathrm{g} / \mathrm{mL})$, G.OLNPs in final concentration ranged $(1.7 \mu \mathrm{g} / \mathrm{mL}$ to $150 \mu \mathrm{g} / \mathrm{mL})$ and itraconazole were adjusted as follows $(0.016 \mu \mathrm{g} / \mathrm{mL}$ to $64 \mu \mathrm{g} / \mathrm{mL})$ against planktonic cells with YNB medium (YNB; $0.67 \%$ yeast nitrogen base, amino acids, $2 \%$ dextrose; Difco Laboratories, Detroit, MI, USA) were added in 96-well microtiter plates (Costar. 3599, Corning). After the addition of inocula stock suspend $\left(1 \times 10^{3}\right.$ cells $\left./ \mathrm{mL}\right)$ prepared as described above, plates were incubated at $35{ }^{\circ} \mathrm{C}$ for 24 and $48 \mathrm{~h}$ to determine MIC values. The Minimal Inhibitory Concentrations (MICs) were determined visibly with the aid of a reading mirror, according to NCCLS guidelines. SubMIC90 were defined as the lowest concentrations exhibiting $<90 \%$ inhibition of visible growth compared with the growth of a drug free control. MFC (Minimal Fungicidal Concentration) were defined as the lowest concentrations that did not allow visible growth on subculture when $10 \mu \mathrm{l}$ of the well content were cultured on SDA agar for $24 \mathrm{~h}$ at $37^{\circ} \mathrm{C}$. To avoid antifungal carryover, aliquots were deposited at a spot on the agar plate and allowed to soak then streaking was performed as described by Moore et al. [38]. Each experiment was repeated in duplicate. 


\subsubsection{Biofilm formation and drug treatment}

Fungal biofilm was studied as describe on commercially available, pre-sterilized, microtiter plate model with minor modification [38]. Briefly, aliquots of $100 \mu \mathrm{L}$ of the standardized cell suspensions of $C$. albicans $\left(1 \times 10^{3}\right.$ cells $\left./ \mathrm{mL}\right)$ in YNB medium containing $100 \mathrm{mM}$ D-glucose were transferred into each well of 96-well polystyrene microtiter plates that was previously coated with BSA (Bovin Serum Albumin), and incubated $90 \mathrm{~min}$ in an orbital shaker (Stuart Scientific, UK75rpm) at $37^{\circ} \mathrm{C}$. After the adhesion phase, the liquid was aspirated and each well was washed three times with sterile PBS to remove loosely attached cells. For mature biofilm to develop, $100 \mathrm{~mL}$ of dilutions of antifungal agents in fresh YNB medium containing $100 \mathrm{mM}$ D-glucose and fresh RPMI - MOPS in a total volume of $200 \mu \mathrm{L}$ were added to biofilms for $48 \mathrm{~h}$ in an orbital shaker at $37^{\circ} \mathrm{C}$. For a subset of assays, after $24 \mathrm{~h}$ of drug treatment, biofilms were washed with PBS. The concentrations studied were as follows: G.EOs and G.OLNPs $(2.3 \mu \mathrm{g} / \mathrm{mL}$ to $150 \mu \mathrm{g} / \mathrm{mL})$ and ITZ at concentrations ranging $(0.04 \mu \mathrm{g} / \mathrm{mL}$ to $64 \mu \mathrm{g} / \mathrm{mL})$ as standard antifungal drug, were added to each well and the plates incubated for $24 \mathrm{~h}$ at $37^{\circ} \mathrm{C}$. Each assay was performed in triplicate and repeated in two independent experiments.

\subsubsection{Quantitative Analysis - XTT Reduction Assay}

The metabolic activity of biofilms was quantified using the (XTT) 2,3-bis (2-methoxy-4-nitro-5-sulfophenyl)-5-[8(phenylamino)carbonyl]-2H-tetrazolium hydroxide reduction assay established by Ramage et al. [4]. Following incubation the cells for the required period, a supernatant was thoroughly removed and plate well was washed twice with $200 \mathrm{ml}$ sterile PBS. The fungal cell viability was quantified using a colorimetric XTT (Sigma, St Louis, MO, USA) assay that would reduce XTT tetrazolium salt to XTT formazan by measuring, the activity of mitochondrial dehydrogenase [39].

Briefly, a saturated solution of XTT was dissolved in Ringer's lactate to $1 \mathrm{mg} / \mathrm{mL}$. This XTT solution was filter sterilized $\left(0.22 \mathrm{~mm}\right.$ pore size filter) and stored at $-70{ }^{\circ} \mathrm{C}$. menadione (sigma) was dissolved in acetone to $1 \mathrm{mM}$. The reagent was prepared fresh prior to each assay and contained 12.5 parts XTT/1 part menadione. $100 \mu \mathrm{L}$ XTT/ menadione were added to each well with prewashed biofilms and incubated for $3 \mathrm{~h}$ in dark conditions at $37^{\circ} \mathrm{C}$.

The colorimetric change during XTT assay, expressed as OD, was measured using a microtiter plate reader at A505 [40]. Higher OD values indicate an increased number of surviving candida in the biofilm. Percentage inhibition was calculated using this equation (A490 of the test/
A490 of the non-treated control) $\times 100 \%$. The results were expressed MBIC50 and MBIC90 were defined as the concentration that showed $50 \%$ and $90 \%$ inhibition of biofilm formation. All experiments were performed in triplicate. YNB medium containing no inoculum (no biofilm) was used as control. The results were expressed as average \pm standard deviation (SD).

\section{Molucular Activity}

\subsection{RT - PCR (Reverse transcriptase - polymerase chain reaction) analysis of ALS1/ALS3 genes}

RT - PCR analysis was conducted as described previously [41]. For RNA extraction and analyse the expression of ALS1 and ALS3 genes, a $24 \mathrm{~h}$ biofilm cultures grown with and without treatment in MICs concentration of G.EOs and G.OLNPs in 12-well tissue culture polystyrene plates was isolated. The RNA extracted was reverse transcribed to cDNA and subjected to PCR using ALS1/ALS3 gene-specific primers (Table 1). Briefly, after re-suspending the biofilms by pipetting was washed gently with sterile PBS. The cells were re-suspended in $200 \mu \mathrm{L}$ of lysis buffer containing (200 mM Tris-Hcl $[\mathrm{pH}=7.5] ; 10 \mathrm{mM}$ EDTA $[\mathrm{pH}=8.0]$; $0.5 \mathrm{M} \mathrm{NaCl}), 200 \mu \mathrm{L}$ of phenol-chloroform-isoamylalchol $(25: 24: 1)$ and glass beads, were mixed, and the tube was strongly vibrate for $60 \mathrm{~min}$. After centrifuging at $5000 \mathrm{rpm}$ for $3 \mathrm{~min}$, the supernatant was transferred to a new tube, and $300 \mu 1$ of choloroform was added. After centrifuging, the aqueous phase was moved to a clean tube and then 1 volume of cold isopropanol was added and reserved at $-20{ }^{\circ} \mathrm{C}$ for $15 \mathrm{~min}$. On the other, the sample was washed twice with $70 \%$ ethanol and with $30 \mu$ distilled water kept at $-20{ }^{\circ} \mathrm{C}$. The RNA samples were treated with $1 \mathrm{U}$ of DNase (Fermentas) per $10 \mu \mathrm{L}$ of RNA at $37^{\circ} \mathrm{C}$ for $1 \mathrm{~h}$ and then its quality checks by electrophoresis on agarose gel (Merck). Synthesis of cDNA was using 2-step RT-PCR Kit (Vi-vantis, Malaysia) according to the manufacturer's instruction and directly used in RT - PCR assay. The reaction solution consisted of $2 \mu \mathrm{L} 10 \mathrm{X}$ Viva Buffer A, $18.5 \mu \mathrm{L}$ distilled water, 1-2 $\mu \mathrm{L}$ cDNA and $0.35 \mu \mathrm{L}$ both forward and reverse primers for each gene. In continue, the microtube put into thermocyler (Techne, TC-512, UK) according to the following procedure: Initial denaturation step at $94{ }^{\circ} \mathrm{C}$ for 5 min followed by 35 cycles consisting of denaturation $\left(1 \mathrm{~min}\right.$ at $\left.94{ }^{\circ} \mathrm{C}\right)$, annealing $\left(1 \mathrm{~min}\right.$ at $\left.58^{\circ} \mathrm{C}\right)$, and extension $\left(1 \mathrm{~min}\right.$ at $\left.72^{\circ} \mathrm{C}\right)$ were followed by a final extension step at $72{ }^{\circ} \mathrm{C}$ for $3 \mathrm{~min}$. Finally, $25 \mu \mathrm{l}$ of PCR product was electrophoresed on $1.5 \%$ agarose gel, stained with ethidium bromide, illuminated and documented Biorad 
Table $1 A L S 1, A L S 3$ (invasion / adhesion genes) and $A C T 1$ (actin reference gene) specific primers for reverse transcriptionpolymerase chain reaction assay. Forward (F) and reverse (R) primers used in RT-PCR

\begin{tabular}{lccc}
\hline Gene & Primer Sequence $\left(5^{\prime} \rightarrow 3^{\prime}\right)$ & $\begin{array}{c}\text { PCR } \\
\text { product } \\
\text { size } \\
(\mathrm{bp})\end{array}$ & $\begin{array}{c}\text { Accession } \\
\text { number }\end{array}$ \\
\hline ALS1-F & GACTAGTGAACCAACAAA & & \\
TLS1-R & ACCAGAAGAAACAGCAGGTG & 318 & L25902 \\
ALS3-F & CCAAGTGTTCCAACAACT & & \\
ALS3-R & GAACCGGTTGTTGCTATGGT & & AY223552 \\
ACT1-F & CCAGCTTTCTACGTTTCC & 200 & HM997110 \\
ACT1-R & CCAGCTTTCTACGTTTCC & & \\
\hline
\end{tabular}

UV Transilluminator [41]. ACT1 (actin) gene was used as a control housekeeping gene.

\subsection{Statistical analysis}

Statistical analysis was performed using SPSS software (SPCC-Statistical Package for the Social Sciences, Inc., Chicago, USA) and the results were compared using a oneway ANOVA followed Bonferroni test. The significance level was set at $p \leq 0.05$.

\section{Results}

\subsection{Interaction studies of Gymnema sylvestre oil with CS-MA Nanogel}

In the present study, CS-MA Nanogels were synthesized by self-assembly method. EDC was used as a cross-linker in order to produce CS-MA Nanogel. As mentioned before, the EDC-mediated attachment of the non-polar fatty acid (MA) to CS polymer in a polar environment (water), led to self-aggregation of non-polar heads inside ward and polar heads outside ward were detected [42].

The as-synthesized G.OLNPs, average particle size, global morphology and uniform share were studied using by SEM (Fig. 1). AFM analysis depicted CSNPs size to be 50-100 nm with quite uniformity in both size and shape. The particle size of the final product was clearly observed to depend on planned parameters as passing the Nanogel through the filter, resonicasion and initial sonication during the synthesis procedure (Fig. 2). The designed nanoparticles have average particle size of less than $100 \mathrm{~nm}$ were recorded. The observation from TEM gave us information about the particle shape and the determination of particle size and physical aggregation of nanoparticles (Fig. 3).

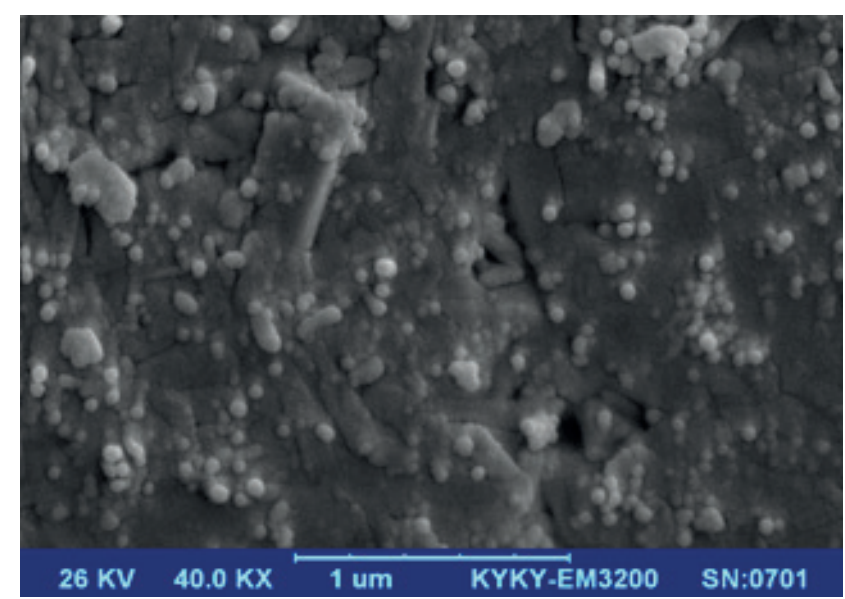

Fig. 1 Scanning electron microscopy (SEM) of the encapsulated G. sylvestre essential oils in Nanogel (G.OLNPs)

The release behavior of G.OLNPs in PBS buffer $(\mathrm{pH}=7.4)$ for 7 days is described in (Fig. 4). As shown, all loaded essential oils were released during one week. On such basis, the MIC experiments were conducted during one week as well. At $30^{\circ} \mathrm{C}$, the cumulative release of G.OLNPs started at $\mathrm{t}=24 \mathrm{~h}$ with $46.37 \pm 2.76 \%$ of total G.OLNPs was slow until $\mathrm{t}=72 \mathrm{~h}$ when the release increased to a cumulative release of $85.04 \pm 2.87 \%$ at $\mathrm{t}=120 \mathrm{~h}$. At $\mathrm{t}=168 \mathrm{~h}, 98.36 \pm 2.38 \%$ of the total quantity of G.OLNPs was released.

The XRD spectrum demonstrated the crystalline structure of the precipitant. As revealed in Figs. 5 and 6. Five distinct reflections are present in the diffractogram at $28.35^{\circ}(111), 43.52^{\circ}(200), 58.15^{\circ}(220), 68.6^{\circ}$ (311), $75.34^{\circ}(222)$. These five reflections represent the face centered cubic (fcc) structure of G.OLNPs. The strong reflection at (111), in contrast with the other four reflections may

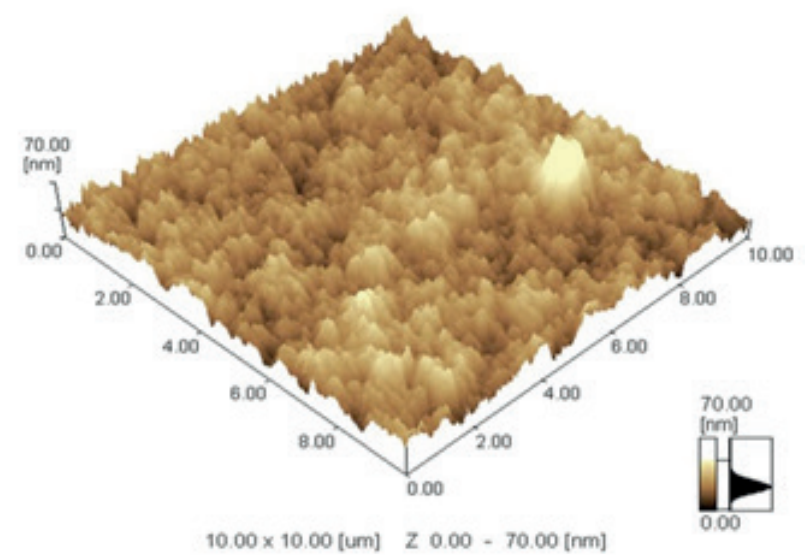

Fig. 2 Atomic Force Microscope (AFM) image. G.OLNPs was taken at room temperature 


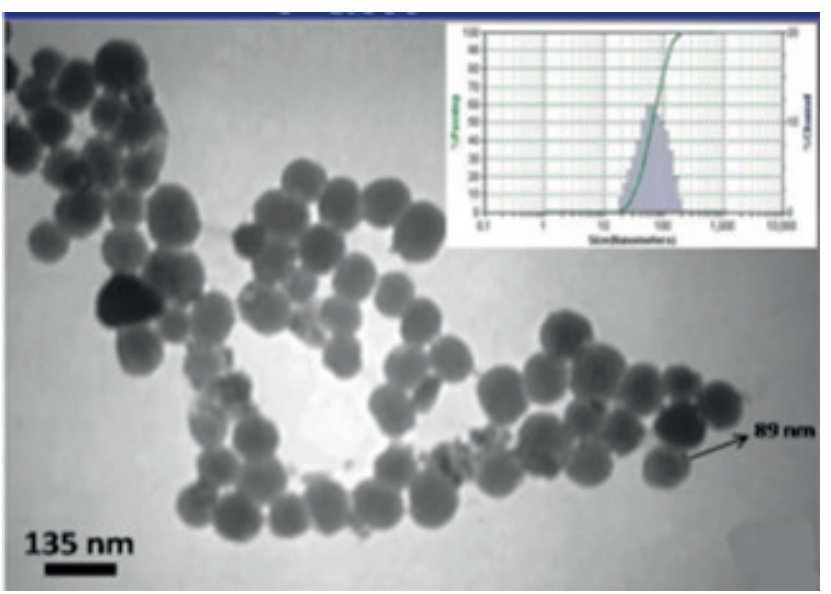

Fig. 3 Transmission electron microscopy (TEM) of the G.OLNPs.

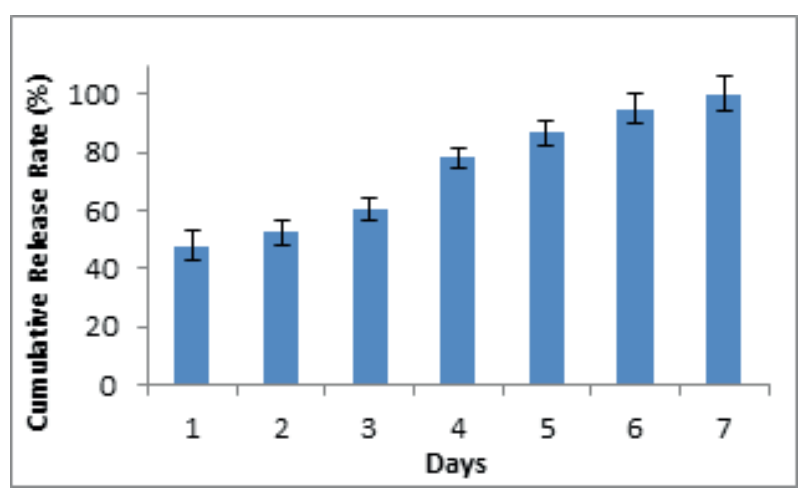

Fig. 4 Release kinetic of CS-MA Nanogel encapsulated G. sylvestre essential oils during one we

specify the desired development track of the nano crystals. Unassigned peaks were also determined; indicate that the crystallization of bioorganic phase develops on the surface of the nanoparticles [43]. Same results were described in G.OLNPs produced by using G.EOs.

Fourier transform infrared spectroscopy (FTIR) of CS shows characteristic peaks at 3433,2920,1647, 1088 and $660.35 \mathrm{~cm}^{-1}$. Wide band at $3433 \mathrm{~cm}^{-1}\left(\mathrm{OH}\right.$ and $\mathrm{NH}_{2}$ stretching), the bands at $2920 \mathrm{~cm}^{-1}$ represent to symmetric and asymmetric stretching vibration of methyl groups (C-H) and the band at $1647 \mathrm{~cm}^{-1}$ (amide I) were measurement.

The symmetrical stretch of the carboxylate group can be assigned to the bands existing at $1426.94 \mathrm{~cm}^{-1}$. The peak at $\sim 1088 \mathrm{~cm}^{-1}$ was due to (C-O stretching). New peaks appeared at $1280 \mathrm{~cm}^{-1}$ (C-N stretch) in the spectrum CS-MA Nanogel implying the complex formation via electrostatic interaction between $\mathrm{NH}_{3}^{+}$groups of CS and carboxyl groups of EDC within the nanoparticles. All the above characteristic peaks also were recorded in the spectra of G.OLNPs. The majority absorbance bands exiting in the spectrum of G.OLNPs were at $3442.20 \mathrm{~cm}^{-1}$ could stretch vibration of $\mathrm{OH}^{-}$alcohol

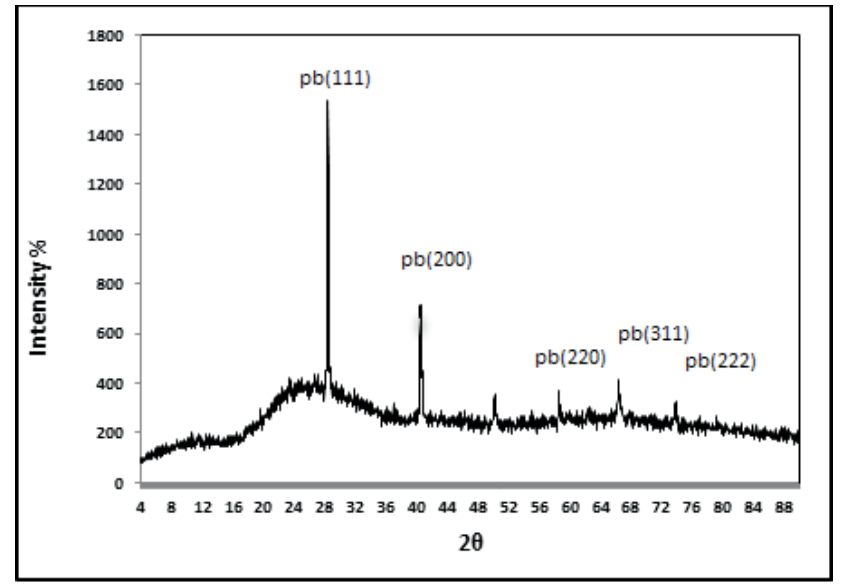

Fig. 5 X-ray diffraction (XRD) pattern of the CS-MA Nanogel.

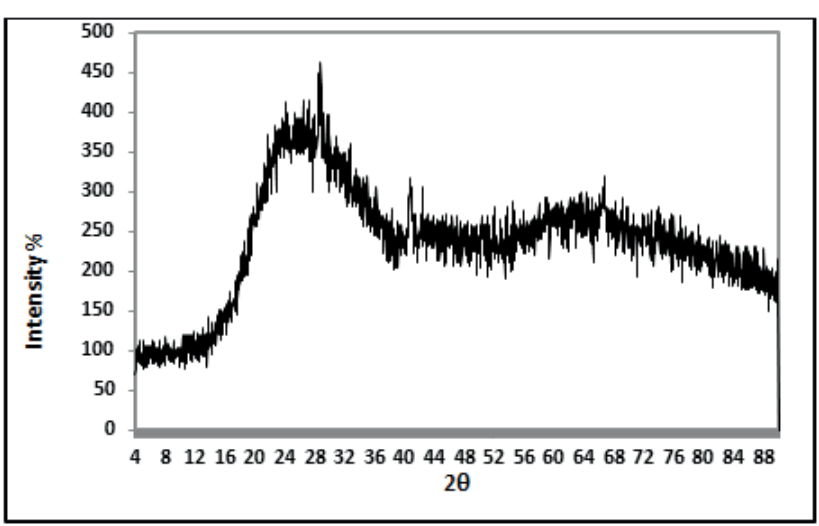

Fig. 6 X-ray diffraction (XRD) pattern of the G.OLNPs

groups. The strength band found at $1641 \mathrm{~cm}^{-1}$ is designated to attribute asymmetrical stretch of the carboxylate group. The symmetrical stretch of the carboxylate group can be assigned to the bands existing at $1280 \mathrm{~cm}^{-1}$. It proves that G.EOs bounce to the nanoparticles surfaces either through amino or carboxylate group or both (Fig. 7).

\subsection{Determination of the Minimum Inhibitory Concentration}

Table 2 summarize the in vitro susceptibility patterns of C. albicans ATCC 10231, including MIC50, MIC90, MFC and the range of MIC values of the G. sylvestre essential oils (G.EOs), essential oil loaded in nanoparticles (G.OLNPs) and ITZ. Our study showed that, the widest range and lowest MIC for ITZ (0.016 to $64 \mu \mathrm{g} / \mathrm{mL}$ ). So that, ITZ the better antifungal effect than G.OLNPs, but this property for G.OLNPs was greater than G.EOs in vitro condition. G.OLNPs, with a MIC50 of $2.3 \mu \mathrm{g} / \mathrm{mL}$, MIC90 of $4.68 \mu \mathrm{g} / \mathrm{mL}$ and MFC $5.38 \mu \mathrm{g} / \mathrm{mL}$, was recorded antifungal effect against $C$. albicans. On the other hand, G.EOs $87 \%$ in MIC50 and MIC90 lower inhibitory 


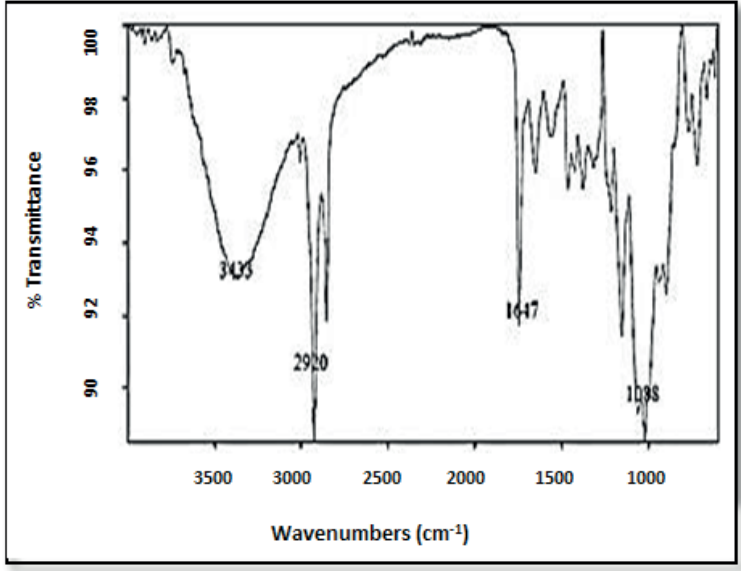

(a)

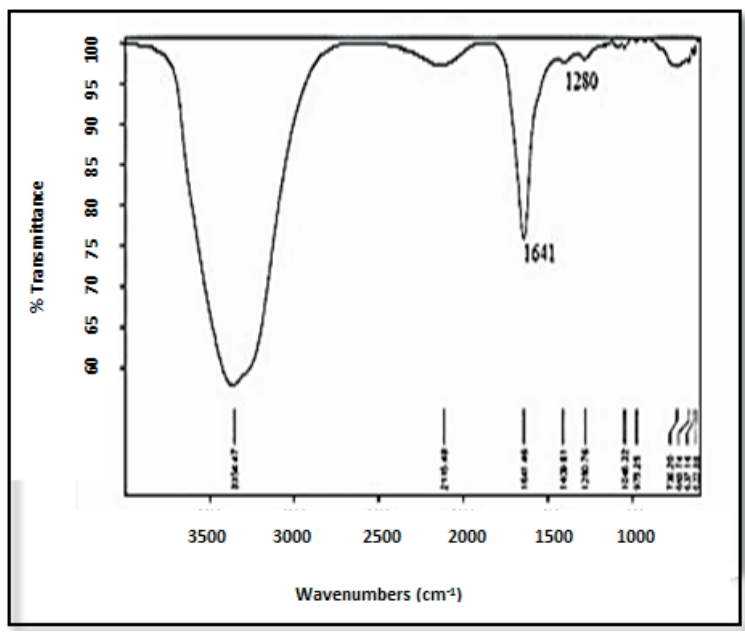

(c)

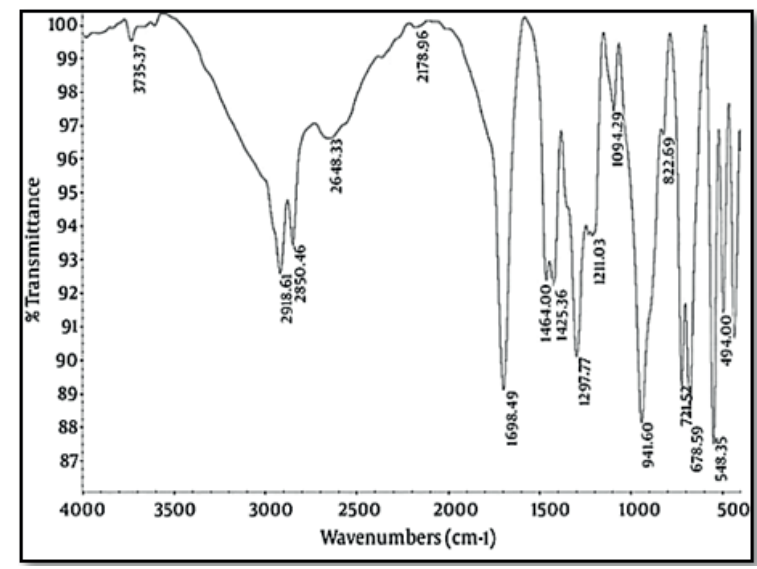

(b)

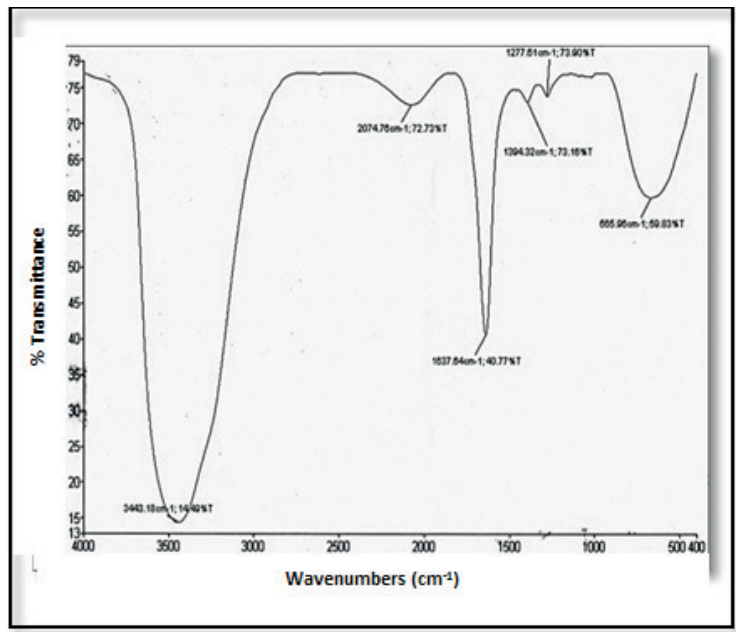

(d)

Fig. 7 FT-IR spectra of (a) CS; (b) CS-MA; (c) MA Nanogel; (d) G.OLNPs

Table 2 Antifungal susceptibility test results for planktonic cells C. albicans ATCC 10231.

\begin{tabular}{lccccc}
\hline \multirow{2}{*}{$\begin{array}{l}\text { Antifungal } \\
\text { agent }\end{array}$} & $\begin{array}{c}\text { MIC } \\
\text { range } \\
(\mu \mathrm{g} / \mathrm{ml})\end{array}$ & $\begin{array}{c}\text { MIC50 } \\
\mu \mathrm{g} / \mathrm{ml}\end{array}$ & $\begin{array}{c}\text { MIC90 } \\
\mu \mathrm{g} / \mathrm{ml}\end{array}$ & $\begin{array}{c}\text { Mean } \pm \\
\text { SD }\end{array}$ & $\begin{array}{c}\text { MFC } \\
\mu \mathrm{g} / \mathrm{ml}\end{array}$ \\
\hline G.EOs & $2.3-300$ & 18.7 & 37.5 & $28.1 \pm 9.4$ & 75 \\
G.OLNPs & $1.17-150$ & 2.3 & 4.68 & $3.49 \pm 1.19$ & 5.38 \\
ITZ & $0.016-$ & $0.063-0.5$ & $\geq 1$ & $0.53 \pm 0.46$ & $\geq 4$ \\
\hline
\end{tabular}

activity than G.OLNPs has been shown. Although MFC of G.EOs is higher than MFC G.OLNPs, but it has the less potent in killing C. albicans planktonic cells $(p<0.05)$.

In concentration of $75 \mu \mathrm{g} / \mathrm{mL}$, the MFC of G.EOs was determined about $93 \%$ lower potential killing activity than G.OLNPs against isolate C. albicans. We found the highest MIC value for G.EOs (18.7 to $37.5 \mu \mathrm{g} / \mathrm{mL}$ ) and the lowest MIC50 (0.063 to $\geq 1 \mu \mathrm{g} / \mathrm{mL})$ was pertained to ITZ. $(p<0.05)$.

\subsection{Prevention of Biofilm Formation}

Generally, the antifungal activity of G.EOs and G.OLNPs against $C$. albicans biofilms was evaluated quantitatively using the XTT reduction assay. The effect was concentration dependent, as reflected by a progressive reduction in cell viability, represent by metabolic activity.

G.EOs, G.OLNPs and ITZ to be inhibited of $50 \%$ sessile cells (MBIC50) in concentration $23.52 \mu \mathrm{g} / \mathrm{mL}$, $4.68 \mu \mathrm{g} / \mathrm{mL}$ and $\geq 16.1 \mu \mathrm{g} / \mathrm{ml}$ respectively and $90 \%$ inhibition of sessile cells (MBIC90) in concentration $60.97 \mu \mathrm{g} / \mathrm{mL}, 18.01 \mu \mathrm{g} / \mathrm{mL}$ and $\geq 24 \mu \mathrm{g} / \mathrm{mL}$ respectively was recorded $(p<0.05)$.

The metabolic activity of the G.OLNPs during biofilm formation $77 \%$ at $9.37 \mu \mathrm{g} / \mathrm{mL}, 46 \%$ at $4.68 \mu \mathrm{g} / \mathrm{mL}$ and $39 \%$ at $2.34 \mu \mathrm{g} / \mathrm{mL}$ was recorded. Therefore, in this inhibitory percentage (MBIC50) G.OLNPs $80 \%$ is more effective of G.EOs, On other hand, in (MBIC90) the inhibitory percentage of G.OLNPs $71 \%$ has been observed effectively (Fig. 8). 


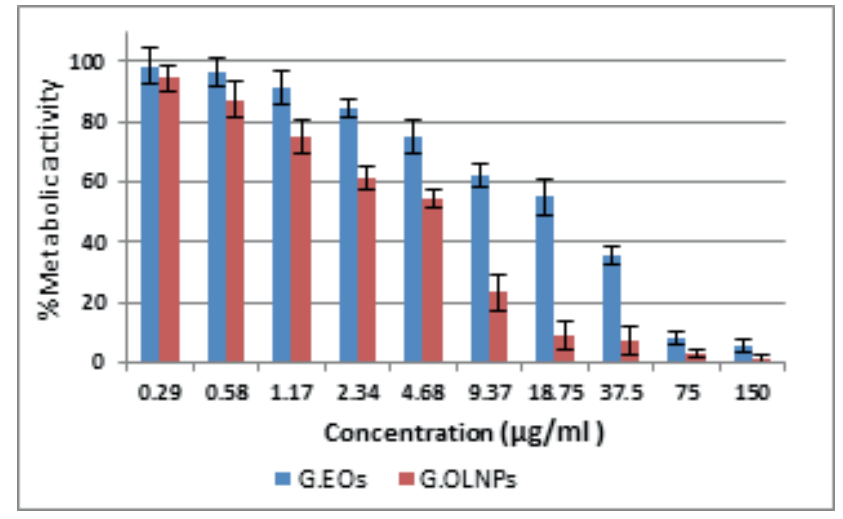

Fig. 8 The metabolic activity of the biofilms was assessed quantitatively using XTT reduction assay. Results shown were the average of three independent experiments $\pm \mathrm{SD}$. $P<0.05$ when compared with the untreated control.

It was shown that nano chitosan essential oil can considerably inhibit the growth of biofilm formation in compared with ITZ.

\subsection{Treatment of $C$. albicans strain with varying concentration of G.EOs / G.OLNPs for gene expression analysis}

The results showed that Actin housekeeping gene was expressed at every concentration of the G.EOs and G.OLNPs. The Figs. 9 and 10 exhibit the representative gel electrophoresis results of the RT - PCR. Slight inconsistent level of Actin expression between different samples is because of different starting amount of RNA used and also the inefficiency of cDNA synthesis. However, this was compensated by the normalization in our calculations. C. albicans treated with G.OLNPs in different concentration based on dose (MIC value) and higher than of MIC shows a general of reduction in ALS3 expression, compared with (MIC value) cells that treated with G.EOs. The ALS3 mRNA was down-regulated in concentration $4.6 \mu \mathrm{g} / \mathrm{mL}$, separately at G.OLNPs and $23.5 \mu \mathrm{g} / \mathrm{ml}$ in G.EOs (Fig. 10).

In contrast of the G.EOs and G.OLNPs there are not apparently significant effects on ALS1 mRNA expression level, as the ALS1/actin ratio remained fairly constant for the conditions tested (Fig. 9). Based on analyses, reduction in the expression of ALS3 gene examined for this study was significant for G.OLNPs. A meaningful relationship was found between the ALS3 gene and biofilm formation in C. albicans isolate in XTT assay.

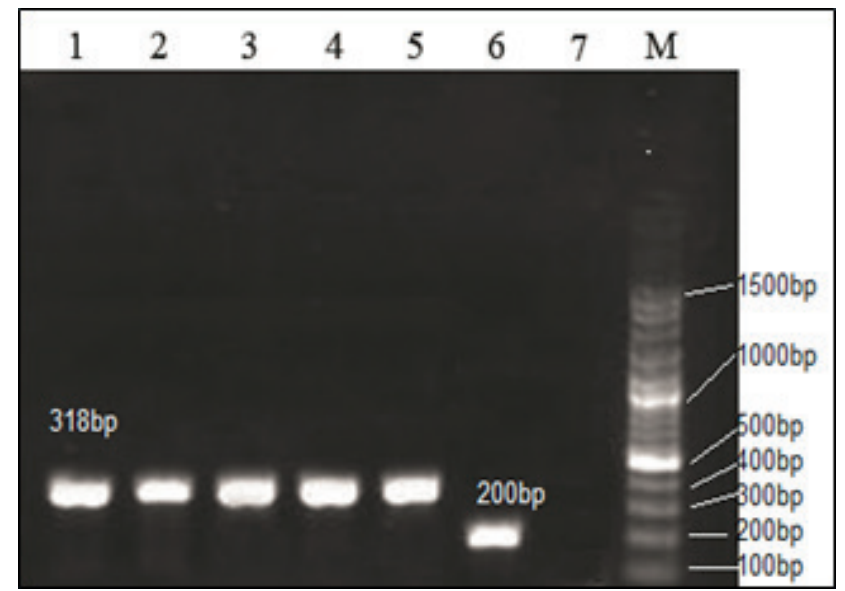

ACT1 23.5 $\uparrow 18.7 \uparrow 4.6 \uparrow 2.3 \uparrow$

Fig. 9 PCR products showing presence of the ALS1 gene of Candida albicans. Line 1: control act1, line 2-3: gene expression of ALS1 in isolate albicans (318 bp) treated with G.EOs; line 4-5: gene expression ALS1 in isolate treated with G.OLNPs. M: Marker molecular weight (100 bp).

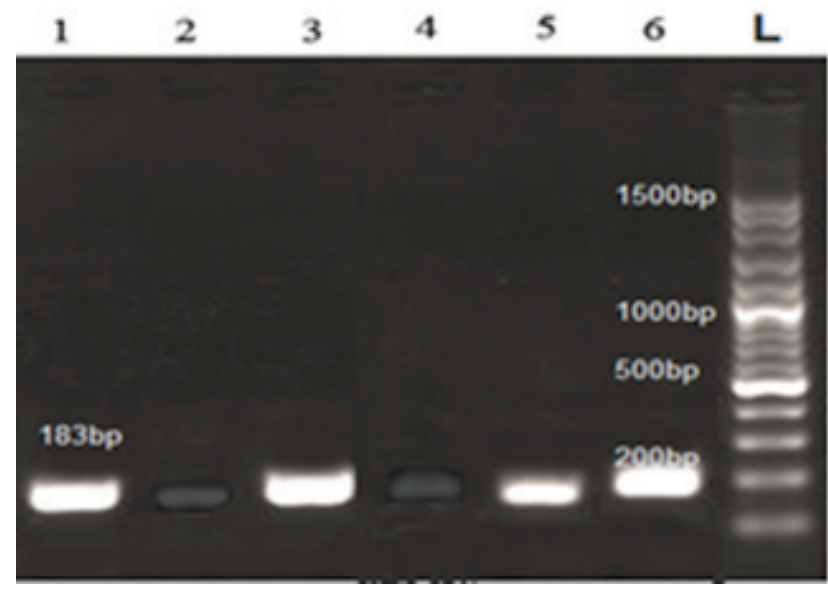

ACT1 23.5 $\uparrow 18.7 \uparrow 4.6 \uparrow 2.3 \uparrow$

Fig. 10 PCR products showing presence of ALS3 gene of Candida albicans. Line 1: control act1; line 2: down-regulated of the gene expression of ALS3 in isolate Candida albicans ATCC10231 (183bp) treated with G.EOs in concentration $23.5 \mu \mathrm{g} / \mathrm{ml}$ and line 3: gene expression of ALS3 with G.EOs in concentration $18.7 \mu \mathrm{g} / \mathrm{ml}$; line 4: down-regulated of the gene expression ALS3 in isolate treated with G.OLNPs in concentration $4.6 \mu \mathrm{g} / \mathrm{ml}$; line 5: gene expression of ALS3 with G.OLNPs in concentration $2.3 \mu \mathrm{g} / \mathrm{ml}$.

\section{Discussion}

The use of nanotechnology in medicine and more specifically drug delivery is set to spread rapidly. For decades, pharmaceutical sciences have been using nanoparticles to reduce toxicity and side effects of drugs. Important strategies are combination therapy; application of drug 
encapsulation in colloidal delivery systems is an efficient approach to improve the pharmacokinetics of hydrophilic drugs and employing nanotechnology [44]. The recourse to naturally occurring products with interesting antifungal, antimicrobial and properties such as chitin and chitosan and their derivatives has been getting more attention in the recent years. It was understood that nanoparticles (NPs) have particular advantages because they not only protect the associated drugs but also facilitate the drugs to go across critical and specific biological barriers. Targets various methods have been developed to fabricate chitosan nano particulate systems. Micro particles and nano chitosan particles are used in tissue engineering, drug delivery and transfer of DNA vaccine [45].

Having considered the above mentioned features of CS and MA, Chitosan has been well reported to be the most widespread biopolymer having nontoxic, biocompatible and biodegradable characteristics [46, 47]. Additionally, chitosan nanoparticles have been proposed as nonviral vectors in gene therapy and shown adjuvant effect in vaccines. Absorption and bioavailability of drug encapsulated into chitosan nanoparticles can be improved, so they can be used to deliver gene drugs, protein drugs, plant drugs and other compounds and can protect them effectively from enzyme degradation in vivo. These extremely robust defence mechanisms of biofilms are lead to investigate approaches to treat biofilm infections. In the drug-delivery field, chitosan can be used as the form of nanoparticles, micro particles, hydrogels, tablets, films, and fibres and can interact with polyanions to from complexes and gels. Recent reports indicate that chitosan exhibits a dose-dependent blood compatibility and cell viability. Exhibited that nano-chitosan particles reduce biofilm formation [48], which in agreement with our findings, and that the more the concentration of these particles, the less biofilm formation, and thus, there is an inverse relationship between the used nanoparticle concentrations and biofilm formation.

On the other hand, connection of $\mathrm{CS}^{\prime} \mathrm{NH}_{4}$ groups to abutting groups such as fatty acids could create derivatives, which bend to dual bonds, and this in turn enables them to form nano micelles in water and to encapsulate fats and oils, e.g. Herbal essential oils. The increased resistance of candida azole drugs and the few drugs available for candida's treatment has led to search for new therapeutic alternative $[49,50]$. EOs is natural plant products comprised of complex mixtures of biologically active substances and offer potential novel template molecules and bioactive compounds [51]. One of the alternatives is herbal plants essential oils. A set of fractions derived from the plant G. sylvestre consistently showed strong repressive activity against $C$. albicans yeast to hypha conversation.

Vediyappan et al. [52] reported GAs had inhibitory activity of $C$. albicans yeast to hypha conversion and sessile cell's biofilm formation (BF) under several hyphae, including conditions such as liquid or solid RPMI and YPD medium containing $10 \%$ fetal bovine serum at $37^{\circ} \mathrm{C}$. Moreover, the results revealed that GAs impaired hyphal growth in the presents of $\mathrm{db}$ cAMP. To further examine the hyphal growth inhibitory activity of GAs, germination and hyphal growth of the filamentous pathogenic fungus Aspergillus fumigatus was tested with $(40 \mu \mathrm{g} / \mathrm{mL})$ [52]. These correlate well with this study, which shows that concentrations of G.OLNPs could suppress hyphae formation several researchers have investigated the antifungal mode by action essential oils on gene expression C. albicans.

ALS1 and ALS3, which belong to the ALS (agglutinin-Like sequence) gene family, encode cell surface glycoproteins [53]. ALS gene diversity genetically is caused protein profile of ALS has different cell-surface as a multifunctional adhesive molecule which mediates adherence to diver's host substrates, such as endothelial cells, oral epithelial cells, gelatine, fibrinogen and laminin and extracellular matrix proteins [54]. It also plays an important role in biofilm formation on prosthetic solid surfaces [55]. In the mature while the ALS1 gene is expressed in the earlier stages of biofilm formation [56], the ALS3 gene is mainly up-regulated biofilm [57]. Therefore, ALS3 is a hypha-specific gene that is expressed by C. albicans hyphae and pseudo hyphae but not yeast phase organisms. ALS3 is a receptor for ferritin and mediates iron acquisition from the host. Therefore, C. albicans can utilize ferritin as the source of iron [58]. As expected from the multifunctional nature of ALS3, mutant strain of C. albicans that lack this protein have prominent defects in assays of host cell interaction, biofilm formation, and iron acquisition in vitro [59]. The fact that ALS3 is highly expressed on the C.albicans surface in vivo makes it a good target for a vaccine. Ibrahim and Spellberg [60] found that vaccination with rALS3-N protects immune competent mice from both vaginal candidiasis and lethal disseminated candidiasis.

Finally, understanding changes in gene expression that are associated with biofilm formation increases the utility of these models for testing of potential inhibitors, and important new information about how C. albicans adherents to host, forms biofilms, and invades host cells. This information also 
holds promise to lead to the development of new approaches to prevent and treat candida infections.

\section{Conclusions}

Taken together, our data demonstrate that G.EOs such as G.OLNPs and ITZ are active on both planktonic and biofilm cells of C. albicans. G.OLNPs was the most effective compound tested by being active against $C$. albicans biofilms, making this compound particularly interesting. Although G.OLNPs was less effective than ITZ on planktonic cells in our model, it is considered a less toxic compound than ITZ by workers in this field of study. The comparison among the results illustrates stronger

\section{References}

[1] Edmond, M. B., Wallace, S. E., McClish, D. K., Pfaller, M. A., Jones, R. N., (Wenzel, R. P. "Nosocomial Bloodstream Infections in United States Hospitals: A Three-Year Analysis", Clinical Infectious Diseases, 29(2), pp. 239-244, 1999.

https://doi.org/10.1086/520192

[2] Aperis, G., Myriounis, N., Spanakis, E. K., Mylonakis, E. "Developments in the treatment of candidiasis: more choices and new challenges", Expert Opinion on Investigational Drugs, 15(11), pp. 1319-1336, 2006.

https://doi.org/10.1517/13543784.15.11.1319

[3] Bujdáková, H. "Management of Candida biofilms: state of knowledge and new options for prevention and eradication", Future Microbiology, 11(2), pp. 235-251, 2016.

https://doi.org/10.2217/fmb.15.139

[4] Ramage, G., Saville, S. P., Thomas, D. P., López-Ribot, J. L. "Candida Biofilms: an Update", Eukaryotic Cell, 4(4), pp. 633-638, 2005.

https://doi.org/10.1128/ec.4.4.633-638.2005

[5] Seneviratne, C. J., Jin, L., Samaranayake, L. P. "Biofilm lifestyle of Candida: a mini review", Oral Diseases, 14(7), pp. 582-590, 2008. https://doi.org/10.1111/j.1601-0825.2007.01424.x

[6] Richard, M. L., Nobile, C. J., Bruno, V. M., Mitchell, A. P. "Candida albicans Biofilm-Defective Mutants", Eukaryotic Cell, 4(8), pp. 1493-1502, 2005.

https://doi.org/10.1128/ec.4.8.1493-1502.2005

[7] Lorenz, M. C., Bender, J. A., Fink, G. R. "Transcriptional Response of Candida albicans upon Internalization by Macrophages", Eukaryotic Cell, 3(5), pp. 1076-1087, 2004.

https://doi.org/10.1128/ec.3.5.1076-1087.2004

[8] Ten Cate, J. M., Klis, F. M., Pereira-Cenci, T., Crielaard, W., De Groot, P. W. J. "Molecular and Cellular Mechanisms That Lead to Candida Biofilm Formation", Journal of Dental Research, 88(2), pp. 105-115, 2009. https://doi.org/10.1177/0022034508329273

[9] Brockert, P. J., Lachke, S. A., Srikantha, T., Pujol, C., Galask, R., Soll, D. R. "Phenotypic Switching and Mating Type Switching of Candida glabrata at Sites of Colonization", Infection and Immunity, 71(12), pp. 7109-7118, 2003. https://doi.org/10.1128/iai.71.12.7109-7118.2003 antifungal effects, especially on planktonic cells, biofilm mass and down-regulated ALS3 expression by G.OLNPs as a potential replacement therapy represents a new era of phytopharmaceuticals. Using combinations of relatively G.OLNPs with relatively expensive antifungals can lower the cost of therapy significantly. Hopefully, in the future, EOs can progress from being one of the traditional curative agents to become a widely used therapy in the modern medical domain.

\section{Acknowledgments}

This work was performed with the support of Tarbiat Modares University Research Council.

[10] Hube, B., Stehr, F., Bossenz, M., Mazur, A., Kretschmar, M., Schäfer, W. "Secreted lipases of Candida albicans: cloning, characterisation and expression analysis of a new gene family with at least ten members", Archives of Microbiology, 174(5), pp. 362-374, 2000. https://doi.org/10.1007/s002030000218

[11] Murciano, C., Moyes, D. L., Runglall, M., Tobouti, P., Islam, A., Hoyer, L. L., Naglik, J. R. "Evaluation of the Role of Candida albicans Agglutinin-Like Sequence $(A l s)$ Proteins in Human Oral Epithelial Cell Interactions", PloS One, 7(3), e33362, pp. 1-9, 2012. https://doi.org/10.1371/journal.pone.0033362

[12] Yeater, K. M., Chandra, J., Cheng, G., Mukherjee, P. K., Zhao, X., Rodriguez-Zas, S. L., Kwast, K. E., Ghannoum, M. A., Hoyer, L. L. "Temporal analysis of Candida albicans gene expression during biofilm development", Microbiology, 153(8), pp. 2373-2385, 2007. https://doi.org/10.1099/mic.0.2007/006163-0

[13] Bastidas, R. J., Heitman, J., Cardenas, M. E. "The Protein Kinase Tor1 Regulates Adhesin Gene Expression in Candida albicans", PLoS Pathogens, 5(2), e1000294, pp. 1-12, 2009. https://doi.org/10.1371/journal.ppat.1000294

[14] Silva, S., Henriques, M., Martins, A., Oliveira, R., Williams, D., Azeredo, J. "Biofilms of non-Candida albicans Candida species: quantification, structure and matrix composition", Medical Mycology, 47(7), pp. 681-689, 2009. https://doi.org/10.3109/13693780802549594

[15] Jain, N., Kohli, R., Cook, E., Gialanella, P., Chang, T., Fries, B. C. "Biofilm Formation by and Antifungal Susceptibility of Candida Isolates from Urine", Applied and Environmental Microbiology, 73(6), pp. 1697-1703, 2007. https://doi.org/10.1128/aem.02439-06

[16] Nailis, H., Vandenbosch, D., Deforce, D., Nelis, H. J., Coenye, T. "Transcriptional response to fluconazole and amphotericin B in Candida albicans biofilms", Research in Microbiology, 161(4), pp. 284-292, 2010. https://doi.org/10.1016/j.resmic.2010.02.004

[17] ̌ičicová, M., Kucharíková, S., Tournu, H., Hendrix, J., Bujdáková, H., Van Eldere, J., Lagrou, K., Van Dijck, P. "Candida albicans biofilm formation in a new in vivo rat model", Microbiology, 156(3), pp. 909-919, 2010. https://doi.org/10.1099/mic.0.033530-0 
[18] Şenel, S., McClure, S. J. "Potential applications of chitosan in veterinary medicine", Advanced Drug Delivery Reviews, 56(10), pp. 1467-1480, 2004. https://doi.org/10.1016/j.addr.2004.02.007

[19] Agnihotri, S. A., Mallikarjuna, N. N., Aminabhavi, T. M. "Recent advances on chitosan-based micro- and nanoparticles in drug delivery", Journal of Controlled Release, 100(1), pp. 5-28, 2004. https://doi.org/10.1016/j.jconrel.2004.08.010

[20] Velmurugan, A., Loganathan, M., Gunasekaran, E. J. "Experimental investigations on combustion, performance and emission characteristics of thermal cracked cashew nut shell liquid (TC-CNSL)-diesel blends in a diesel engine", Fuel, 132, pp. 236-245, 2014. https://doi.org/10.1016/j.fuel.2014.04.060

[21] Nazem, H., Mohsenifar, A., Majdi, S. "Chitosan-myristate nanogel as an artificial chaperone protects neuroserpin from misfolding", Advanced Biomedical Research, 5(170), pp. 1-6, 2016. http://doi.org/10.4103/2277-9175.190942

[22] Rabea, E. I., Badawy, M. E.-T., Stevens, C. V., Smagghe, G., Steurbaut, W. "Chitosan as Antimicrobial Agent: Applications and Mode of Action", Biomacromolecules, 4(6), pp. 1457-1465, 2003. http://doi.org/10.1021/bm034130m

[23] Sudarshan, N. R., Hoover, D. G., Knorr, D. "Antibacterial Action of Chitosan", Food Biotechnology, 6(3),pp. 257-272, 1992. http://doi.org/10.1080/08905439209549838

[24] Shrestha, A., Shi, Z., Neoh, K. G., Kishen A. "Nanoparticulates for Antibiofilm Treatment and Effect of Aging on Its Antibacterial Activity", Journal of Endodontics, 36(6), pp. 1030-1035, 2010. https://doi.org/10.1016/j.joen.2010.02.008

[25] Das, S. R., Assaf, M. H., Petriu, E. M., Sahinoglu, M. "AliasingFree Compaction in Testing Cores-Based System-on-Chip (SOC) Using Compatibility of Response Data Outputs", Transactions of the SDPS, 8(1), pp. 1-17, 2004

[26] Kanetkar, P., Singhal, R., Kamat, M. "Gymnema sylvestre: A Memoir", Journal of Clinical Biochemistry and Nutrition, 41(2), pp. 77-81, 2007. https://doi.org/10.3164/jcbn.2007010

[27] Pieper, J. S., Hafmans, T., Veerkamp, J. H., van Kuppevelt, T. H. "Development of tailor-made collagen-glycosaminoglycan matrices: EDC/NHS crosslinking, and ultrastructural aspects", Biomaterials, 21(6), pp. 581-593, 2000. https://doi.org/10.1016/s0142-9612(99)00222-7

[28] Chen, X. G., Lee, C. M., Park, H. J. "O/W Emulsification for the Self-Aggregation and Nanoparticle Formation of Linoleic Acid - Modified Chitosan in the Aqueous System", Journal of Agricultural and Food Chemistry, 51(10), pp. 3135-3139, 2003. https://doi.org/10.1021/jf0208482

[29] Lee, K. Y., Kwon, I. C., Kim, Y.-H., Jo, W. H., Jeong, S. Y. "Preparation of chitosan self-aggregates as a gene delivery system", Journal of Controlled Release, 51(2-3), pp. 213-220, 1998. https://doi.org/10.1016/s0168-3659(97)00173-9

[30] Beyki, M., Zhaveh, S., Khalili, S. T., Rahmani-Cherati, T., Abollahi, A., Bayat, M., Tabatabaei, M., Mohsenifar, A. "Encapsulation of Mentha piperita essential oils in chitosan-cinnamic acid nanogel with enhanced antimicrobial activity against Aspergillus flavus", Industrial Crops and Products, 54, pp. 310-319, 2014. https://doi.org/10.1016/j.indcrop.2014.01.033
[31] Paula, H. C. B., Sombra, F. M., Abreu, F. O. M. S., de Paul, R. C. M. "Lippia sidoides essential oil encapsulation by angico gum/chitosan nanoparticles", Journal of the Brazilian Chemical Society, 21(12), pp. 2359-2366, 2010. https://doi.org/10.1590/s0103-50532010001200025

[32] Shigemasa, Y., Matsuura, H., Sashiwa, H., Saimoto, H. "Evaluation of different absorbance ratios from infrared spectroscopy for analyzing the degree of deacetylation in chitin", International Journal of Biological Macromolecules, 18(3), pp. 237-242, 1996. https://doi.org/10.1016/0141-8130(95)01079-3

[33] Chamkouri, N., Khodadoust, S., Ghalavandi, F. "Solid-Phase Extraction Coupled with HPLC-DAD for Determination of B Vitamin Concentrations in Halophytes", Journal of Chromatographic Science, 53(10), pp. 1720-1724, 2015. https://doi.org/10.1093/chromsci/bmv080

[34] Liu, H., Kohler, J., Fink, G. R. "Suppression of hyphal formation in Candida albicans by mutation of a STE12 homolog", Science, 266(5191), pp. 1723-1726, 1994. https://doi.org/10.1126/science.7992058

[35] Rex, J. H., Pfaller, M. A., Galgiani, J. N., Bartlett, M. S., EspinelIngroff, A., Ghannoum, M. A., Lancaster, M., Odds, F. C., Rinaldi, M. G., Walsh, T. J., Barry, A. L. "Development of Interpretive Breakpoints for Antifungal Susceptibility Testing: Conceptual Framework and Analysis of In Vitro-In Vivo Correlation Data for Fluconazole, Itraconazole, and Candida Infections", Clinical Infectious Diseases, 24(2), pp. 235-247, 1997.

https://doi.org/10.1093/clinids/24.2.235

[36] Rodrigueza, W. V., Streeper, R. T., Izbicka, E., Sooch, M. P., Woolliscroft, M. J., Messmann, R. A., Gaylor, S. K., Pronai Therapeutics, Inc. "Methods of Using Biomarkers for the Treatment of Cancer by Modulation of BCL2 Expression", Kalamazzo, USA, United States Patent Application Publication No.: US 2015/0299803 A1, Application No.: 14/440,866, 2015.

[37] Duarte, A., Martinho, A., Luís, Â., Figueiras, A., Oleastro, M., Domingues, F. C., Silva, F. "Resveratrol encapsulation with methyl- $\beta$-cyclodextrin for antibacterial and antioxidant delivery applications", LWT - Food Science and Technology, 63(2), pp. 12541260, 2015.

https://doi.org/10.1016/j.1wt.2015.04.004

[38] Moore, C. B., Walls, C. M., Denning, D. W. "In Vitro Activities of Terbinafine against Aspergillus Species in Comparison with Those of Itraconazole and Amphotericin B", Antimicrobial Agents and Chemotherapy, 45(6), pp. 1882-1885, 2001. https://doi.org/10.1128/aac.45.6.1882-1885.2001

[39] Bandara, H. M. H. N., Lam, O. L. T., Watt, R. M., Jin, L. J., Samaranayake, L. P. "Bacterial lipopolysaccharides variably modulate in vitro biofilm formation of Candida species", Journal of Medical Microbiology, 59(10), pp. 1225-1234, 2010. https://doi.org/10.1099/jmm.0.021832-0

[40] Akbari, A., Chamkouri, N., Zadabdollah, A. "Determination Trace Levels of Vitamin C and Folic Acid in Urine Sample by Ultrasound-Assisted Dispersive Liquid-Liquid Microextraction Method Coupled HPLC-UV", Oriental Journal of Chemistry, 32(6), pp. 3027-3033, 2016.

https://doi.org/10.13005/ojc/320623 
[41] Li, X., Yan, Z., Xu, J. "Quantitative variation of biofilms among strains in natural populations of Candida albicans", Microbiology, 149(2), pp. 353-362, 2003.

https://doi.org/10.1099/mic.0.25932-0

[42] Green, C. B., Cheng, G., Chandra, J., Mukherjee, P., Ghannoum, M. A., Hoyer, L. L. "RT-PCR detection of Candida albicans ALS gene expression in the reconstituted human epithelium (RHE) model of oral candidiasis and in model biofilms", Microbiology, 150(2), pp. 267-275, 2004.

https://doi.org/10.1099/mic.0.26699-0

[43] Lee, K. Y., Kwon, I. C., Kim, Y.-H., Jo, W. H., Jeong, S. Y. "Preparation of chitosan self-aggregates as a gene delivery system", Journal of Controlled Release, 51(2-3), pp. 213-220, 1998. https://doi.org/10.1016/s0168-3659(97)00173-9

[44] Nishitani, Y., Maruyama, D., Nonaka, T., Kita, A., Fukami, T. A., Mio, T., Yamada-Okabe, H., Yamada-Okabe, T., Miki, K. "Crystal Structures of $N$-Acetylglucosamine-phosphate Mutase, a Member of the $\alpha$-D-Phosphohexomutase Superfamily, and Its Substrate and Product Complexes", Journal of Biological Chemistry, 281(28), pp. 19740-19747, 2006.

https://doi.org/10.1074/jbc.m600801200

[45] Nitta, S. K., Numata, K. "Biopolymer-Based Nanoparticles for Drug/Gene Delivery and Tissue Engineering", International Journal of Molecular Sciences, 14(1), pp. 1629-1654, 2013. https://doi.org/10.3390/ijms14011629

[46] Janes, K. A., Calvo, P., Alonso, M. J. "Polysaccharide colloidal particles as delivery systems for macromolecules", Advanced Drug Delivery Reviews, 47(1), pp. 83-97, 2001. https://doi.org/10.1016/s0169-409x(00)00123-x

[47] Dodane, V., Vilivalam, V. D. "Pharmaceutical applications of chitosan", Pharmaceutical Science \& Technology Today, 1(6), pp. 246-253, 1998. https://doi.org/10.1016/s1461-5347(98)00059-5

[48] Muzzarelli, C., Stanic, V., Gobbi, L., Tosi, G., Muzzarelli, R. A. A. "Spray-drying of solutions containing chitosan together with polyuronans and characterisation of the microspheres", Carbohydrate Polymers, 57(1), pp. 73-82, 2004.

https://doi.org/10.1016/j.carbpol.2004.04.002

[49] Azcurra, A. I., Barembaum, S. R., Bojanich, M. A., Calamari, S. E., Aguilar, J., Battellino, L. J., Dorronsoro, S. T. "Effect of the high molecular weight chitosan and sodium alginate on Candida albicans hydrophobicity and adhesion to cells", Medicina Oral Patología Oral y Cirurgía Bucal, 11, pp. E120-E125, 2006.

[50] Runyoro, D. K. B., Ngassapa, O. D., Matee, M. I. N., Joseph, C. C., Moshi, M. J. "Medicinal plants used by Tanzanian traditional healers in the management of Candida infections", Journal of Ethnopharmacology, 106(2), pp. 158-165, 2006.

https://doi.org/10.1016/j.jep.2005.12.010

[51] Hoyer, L. L., Green, C. B., Oh, S.-H., Zhao, X. "Discovering the secrets of the Candida albicans agglutinin-like sequence (ALS) gene family - a sticky pursuit", Medical Mycology, 46(1), pp. 1-15, 2008.

https://doi.org/10.1080/13693780701435317
[52] Mandras, N., Nostro, A., Roana, J., Scalas, D., Banche, G., Ghisetti, V., Del Re, S., Fucale, G., Cuffini, A. M., Tullio, V. "Liquid and vapour-phase antifungal activities of essential oils against Candida albicans and non-albicans Candida", BMC Complementary and Alternative Medicine, 16(330), pp. 1-7, 2016. https://doi.org/10.1186/s12906-016-1316-5

[53] Vediyappan, G., Dumontet, V., Pelissier, F., d'Enfert, C. "Gymnemic Acids Inhibit Hyphal Growth and Virulence in Candida albicans", PloS One, 8(9), e74189, pp. 1-11, 2013. https://doi.org/10.1371/journal.pone.0074189

[54] Eng, C., Clayton, D., Schuffenecker, I., Lenoir, G., Cote, G., Gagel, R. F., Ploos van Amstel, H. K., Lips, C. J. M., Nishisho, I., Takai, S.-I., Marsh, D. J., Robinson, B. G., Frank-Raue, K., Raue, F., Xue, F., Noll, W. W., Romei, C., Pacini, F., Fink, M., Niederle, B., Zedenius, J., Nordenskjöld, M., Komminoth, P., Hendy, G. N., Gharib, H., Thibodeau, S. N., Lacroix, A., Frilling, A., Ponder, B. A. J., Mulligan, L. M. "The Relationship Between Specific RET Proto-oncogene Mutations and Disease Phenotype in Multiple Endocrine Neoplasia Type 2: International RET Mutation Consortium Analysis", Jama, 276(19), pp. 1575-1579, 1996. https://doi.org/10.1001/jama.1996.03540190047028

[55] Liu, Y., Filler, S. G. "Candida albicans Als3, a Multifunctional Adhesin and Invasin", Eukaryotic Cell, 10(2), pp. 168-173, 2011. https://oi.org/10.1128/ec.00279-10

[56] García-Sánchez, S., Aubert, S., Iraqui, I., Janbon, G., Ghigo, J.-M., d'Enfert, C. "Candida albicans Biofilms: a Developmental State Associated With Specific and Stable Gene Expression Patterns", Eukaryotic Cell, 3(2), pp. 536-545, 2004. https://doi.org/10.1128/ec.3.2.536-545.2004

[57] Yeater, K. M., Chandra, J., Cheng, G., Mukherjee, P. K., Zhao, X., Rodriguez-Zas, S. L., Kwast, K. E., Ghannoum, M. A., Hoyer, L. L. "Temporal analysis of Candida albicans gene expression during biofilm development", Microbiology, 153(8), pp. 23732385, 2007. https://doi.org/10.1099/mic.0.2007/006163-0

[58] Kucharíková, S., Tournu, H., Lagrou, K., Van Dijck, P., Bujdáková, H. "Detailed comparison of Candida albicans and Candida glabrata biofilms under different conditions and their susceptibility to caspofungin and anidulafungin", Journal of Medical Microbiology, 60(9), pp. 1261-1269, 2011.

https://doi.org/10.1099/jmm.0.032037-0

[59] Almeida, R. S., Wilson, D., Hube, B. "Candida albicans iron acquisition within the host", FEMS Yeast Research, 9(7), pp. 1000-1012, 2009. https://doi.org/10.1111/j.1567-1364.2009.00570.x

[60] Coleman, M. "Playback: From the Victrola to MP3, 100 Years of Music, Machines, and Money", Da Capo Press, Cambridge, USA, 2009.

[61] Ibrahim, A. S., Spellberg, B. "Chapter 29: Zygomycetes as Agents of Infectious Disease in Humans", In: Heitman, J., Filler, S. G., Edwards, Jr., J. E., Mitchell, A. P. (eds.) Molecular Principles of Fungal Pathogenesis, ASM Press, Washington, D.C., USA, 2006, pp. $428-440$. https://doi.org/10.1128/9781555815776.ch29 